\title{
HISTÓRIA, MEMÓRIA E IDENTIDADE NA GUERRA DE CANUDOS: O INTERDISCURSO NOS POSICIONAMENTOS DO EXÉRCITO BRASILEIRO E DA FOLHA DE SÃO PAULO
}

\begin{abstract}
HISTORY, MEMORY AND IDENTITY IN THE WAR OF CANUDOS: THE INTERDISCURSO IN THE POSITIONING OF THE BRAZILIAN ARMY AND THE LEAF OF SÃO PAULO
\end{abstract}

Recebido em 30.10.2018. Aprovado em 12.06.2019 Avaliado pelo sistema double blind review

\section{Rodrigo Guimarães Motta}

rodrigo-motta@uol.com.br

Programa de Administração e Planejamento/Pontifícia Universidade Católica de São Paulo (PUC-SP) - São Paulo/São Paulo, Brasil

ORCID: 0000-0002-5331-0294

\section{Iara Cristina de Fátima Mola}

iaramola@gmail.com

Programa de Linguística Aplicada e Estudos da Linguagem/Pontifícia Universidade Católica de São Paulo (PUCSP) - São Paulo/São Paulo, Brasil

ORCID: 0000-0003-4761-9030

\section{Resumo}

Este estudo objetiva analisar em que medida o discurso veiculado pela Folha de S.Paulo acerca da Guerra de Canudos por ocasião do seu centenário e do centenário da morte de Conselheiro reproduziria, validaria e/ou refutaria a versão oficial do Exército Brasileiro, depreendendo daí o posicionamento do jornal a esse respeito. Para tanto, foram mobilizados conceitos advindos da História Militar e da Análise do Discurso francesa, aplicados à análise de um corpus constituído de três publicações. Os resultados revelam que a Folha fomenta a (re)construção de uma memória absolutamente contrária àquela veiculada pela versão oficial dos militares, validando-a, inclusive, historicamente.

Palavras-chave: Guerra de Canudos. Antônio Conselheiro. Exército Brasileiro. Folha de S.Paulo. Posicionamento Discursivo.

\begin{abstract}
This study intends to analyze to what extent Folha de S.Paulo's discourse about Canudos War, on the occasion of its centenary and that of Conselheiro's death, would reproduce, validate and/or refute the official version by the Brazilian Army. To do so, concepts derived from Military History and French Discourse Analysis were applied to the analysis of a corpus made of three publications. Results reveal that Folha encourages the (re)construction of a memory completely contrary to that conveyed by the military version, and even validating it historically.
\end{abstract}

Keywords: War of Canudos. Antônio Conselheiro. Brazilian Army. Folha de S.Paulo. Discursive Positioning. 


\section{Introdução}

Para além de toda a cobertura realizada na época da Guerra de Canudos - a exemplo do que se acompanhou em 1897 por meio do trabalho de Euclides da Cunha (2016) -, a inscrição desse conflito histórico-militar como sendo um dos maiores movimentos de resistência popular da história brasileira (se não o maior, efetivamente) lhe rendeu tamanha projeção que, passados mais de cem anos do seu desfecho, a Campanha segue fomentando grande interesse. Dentro e fora da esfera acadêmica, ainda hoje suscita diferentes posicionamentos entre renomados estudiosos e autoridades de campos do conhecimento distintos, assim como entre diversos veículos de comunicação nos quais o tema é retomado tanto como assunto central quanto em livre associação a outros eventos.

Quando tratado, porém, como tópico sobre o qual a publicação discorre com exclusividade, quais destaques lhe seriam conferidos pelo campo jornalístico, especialmente por aqueles jornais classificados como sendo os de maior circulação em território nacional? Quais memórias evocadas pelos próprios jornais atravessariam esse acontecimento histórico quando por eles reproduzido, influenciando nos processos de construção das memórias individual, coletiva e social dos seus próprios leitores? Nesse sentido, as suas publicações recuperariam as narrativas consideradas "oficiais" (como os registros publicados pelo Exército Brasileiro e/ou pela obra euclidiana) a fim de - aparentemente - apenas reproduzi-las ou assim o fariam no propósito de validá-las ou rejeitá-las? Com efeito, qual seria o seu posicionamento acerca do que foi a Guerra de Canudos com suas respectivas motivações e consequências?

Referência mais recente que sobressai entre os mais importantes estudos compartilhados pela comunidade acadêmica e que se volta à reverberação desse conflito por parte de uma instituição específica é o de Pinheiro (2011, 2015), cuja proposta consistiu em realizar uma análise diacrônica do discurso jornalístico sobre a Campanha de Canudos tomando como objeto de análise a ampla cobertura que o jornal O Estado de S.Paulo realizou durante o conflito e que se estendeu até a atualidade. Segundo a autora[1], se, durante a guerra, o jornal inicialmente associou Canudos à República ameaçada, visando a justificar a necessidade de uma ação bélica contra os sertanejos, retratando estes últimos como "fanáticos", "bandidos" e "inimigos", no século XXI ele rompeu com o discurso que legitimava a destruição do arraial antirrepublicano e passou à crítica desse confronto (PINHEIRO, 2015).

Conforme é possível inferir, se, outrora, a visão desse jornal influenciou toda uma geração de leitores no que diz respeito à percepção individual do conflito, o fato é que, desde então, pode-se deduzir que essa mudança de perspectiva também passou a influir nos processos de construção da memória desses leitores, uma vez que, tal como assinala a própria doutora em Comunicação e Cultura Contemporâneas, “o acontecimento (social, histórico ou jornalístico), que só pode ser conhecido e compartilhado por meio do discurso, transforma-se naquilo que o expressa" (PINHEIRO, 2015, p. 303).

Assim, tendo em vista: (i) o conhecimento dos registros publicados pelo Exército Brasileiro acerca da Guerra de Canudos (registros esses aqui tomados como "versão oficial" [2], por corresponder à narrativa das forças militares, que interviram nesse confronto), (ii) a influência do noticiário jornalístico na leitura e compreensão de fatos e documentos históricos (e, portanto, a sua influência para a (re)construção da memória); (iii) o conceito de interdiscurso segundo a Análise do Discurso de vertente francesa, no qual todo discurso "tem a propriedade de estar em relação multiforme com outros discursos" (CHARAUDEAU; MAINGUENEAU, 2008); e (iv) que a Folha de S.Paulo "é hoje o jornal brasileiro de maior tiragem e circulação entre os diários nacionais de interesse geral"'[3], o objetivo desta pesquisa consiste em analisar em que medida o discurso veiculado pelo jornal Folha de S. Paulo acerca da Guerra de Canudos por ocasião do seu centenário e do centenário da morte de Conselheiro reproduz, valida e/ou refuta a versão/o discurso oficial do Exército Brasileiro, depreendendo-se daí, portanto, o próprio posicionamento desse veículo de comunicação no que tange a esse acontecimento. 
O estudo ora proposto consiste numa pesquisa aplicada de natureza teórica, de caráter exploratório e abordagem qualitativa, cuja análise do corpus seguiu um processo indutivo. No que tange ao seu arcabouço teórico, propôs-se uma articulação entre as noções de história, memória e identidade sob a perspectiva da História Militar de um lado e, de outro, o conceito de interdiscurso e a noção de posicionamento discursivo emprestados da Análise do Discurso de vertente francesa, ambos também tomados como categoria de análise, dado corresponderem a ferramentais teórico-metodológicos dessa segunda disciplina.

Em relação à sua origem, postula-se que a Análise do Discurso de linha francesa (doravante, “AD”) nasceu sob o signo da articulação entre a Linguística (Estruturalismo), o Materialismo Histórico e a Psicanálise. Com o tempo, porém, a AD entrou em contato com outras áreas do conhecimento, com as quais estabelece diálogos por entender que a linguagem faz sentido para sujeitos que ocupam posições sociais ou que estão inseridos em conjunturas históricas.

Para o linguista francês Dominique Maingueneau, principal acadêmico em evidência no momento atual, "a unidade de análise pertinente não é o discurso, mas um espaço de trocas entre vários discursos convenientemente escolhidos" (MAINGUENEAU, 2008, p. 20). Sob essa perspectiva, o teórico se refere ao interdiscurso [4] como esse espaço de regularidade pertinente, do qual os diversos discursos existentes são apenas componentes, ou seja, eles "não se constituem independentemente uns dos outros, para serem, em seguida, postos em relação", mas "se formam de maneira regulada no interior do interdiscurso". Para ele, portanto, "seria a relação interdiscursiva que estruturaria a identidade" (MAINGUENEAU, 2008, p. 21). Essa "identidade", por sua vez, não é "fechada" nem pode ser reivindicada como "autônoma": trata-se de uma ilusão, posto que o Outro está na raiz do Mesmo do discurso; "ele é aquele que faz sistematicamente falta a um discurso e lhe permite encerrar-se como um todo. É aquela parte de sentido que foi necessário o discurso sacrificar para constituir a própria identidade" (MAINGUENEAU, 2008, p. 37, grifos nossos).

É desse espaço interdiscursivo, portanto, que se pode depreender o que a AD nomeará "posicionamento discursivo", uma de suas categorias de base "que diz respeito à instauração e à conservação de uma identidade enunciativa" (CHAUREDEAU; MAINGUENEAU, 2008, p. 392). Neste estudo, a noção de posicionamento corresponde à posição que um locutor (no caso, a Folba de S.Paulo) ocupa em um campo de discussão, aos valores que ele defende (consciente ou inconscientemente, sendo que, no caso da Folha, ela apresenta "pluralismo", "apartidarismo", "jornalismo crítico" e "independência" como princípios editoriais (O JORNAL..., 2018)) e que caracterizam reciprocamente sua identidade social e ideológica.

Por fim, ainda no que diz respeito ao conceito de interdiscurso, Maingueneau (2015, p. 28) postula que, para interpretar o menor enunciado, "é necessário relacioná-lo, conscientemente ou não, a todos os tipos de outros enunciados sobre os quais ele se apoia de múltiplas maneiras". Sob esse entendimento é que, acerca da Guerra de Canudos, optou-se por se relacionar aqui o discurso da Folha de S.Paulo e o do Exército Brasileiro, sendo este tomado tanto como autoridade correlacionária da versão oficial dos acontecimentos como, por isso mesmo, o Outro com o qual o discurso do referido veículo jornalístico dialogaria, fazendo-se presente na sua "raiz", restando saber, no entanto, de que forma essa relação se daria.

Assim, uma vez conhecida a publicação das forças militares acerca da Campanha de Canudos e já definido o excerto que comporia o conjunto de documentos analisados, restava a seleção dos artigos, para a qual foi realizado um levantamento por meio do mecanismo de busca disponibilizado no site da Folha, em que foram adotados critérios iniciais que conduziram a 60 resultados. Destes, foram excluídas matérias que se reportavam ao lançamento de um filme sobre Canudos, chamadas para cronologias da Guerra e outros títulos que se referiam diretamente a Euclides da Cunha. Isto porque, visando-se ao comparativo com o excerto destacado da publicação do site do Exército Brasileiro, os recortes a serem efetuados para efeito de análise deveriam se concentrar, prioritariamente, nas apreciações em torno de Antônio Conselheiro líder de Canudos - e nos chamados conselheiristas, bem como naquelas em torno da motivação para a guerra e/ou em torno da intervenção militar, propriamente. 
Após algumas leituras prévias, chegou-se à análise dos seguintes documentos: o artigo de opinião "O Bom Jesus do sertão", de autoria do renomado historiador José Calasans, publicado em 21 de setembro de 1997 no caderno +Mais! por ocasião do centenário da morte de Antônio Conselheiro, e o artigo de opinião "Canudos sobrevive", do então diretor editorial do Grupo Folha, Otávio Frias Filho, publicado em 2 de outubro do mesmo ano na seção Opinião por ocasião do centenário do desfecho de Canudos. Desta forma, para que não houvesse dúvida quanto ao posicionamento do veículo a respeito desse tema, estabeleceu-se que o corpus incluiria tanto um artigo de opinião assinado por um profissional cujo posicionamento manifestasse objetivamente o próprio posicionamento desse veículo de comunicação (caso de Frias Filho) quanto um artigo de opinião assinado por um profissional convidado a escrever em caráter especial para a Folha, de cujo posicionamento se pudesse inferir a corroboração advinda do próprio Jornal (caso de Calasans).

Este artigo encontra-se estruturado da seguinte forma: primeiramente, é apresentada uma breve contextualização da Guerra de Canudos, na qual foram considerados os três aspectos que serão retomados por ocasião da análise: o líder, seus seguidores e o início da guerra. Na sequência, discorre-se sobre os conceitos de história, memória e identidade consoante a perspectiva da História Militar, a partir dos quais se desenvolve a fundamentação teórica deste estudo. Por fim, empreende-se a análise dos resultados, que inclui uma subseção, haja vista que são comparadas as versões do Exército Brasileiro e de Calasans como convidado da Folha e, depois, as de Calasans como convidado da Folha e de Frias Filho como diretor desse jornal, precedendo as considerações finais.

\section{Antônio Conselheiro e a Guerra de Canudos: várias versões, uma síntese}

De acordo com a recapitulação histórica que Nogueira (1978) propõe em sua obra "Antônio Conselheiro e Canudos"[5], Antônio Conselheiro - alcunha de António Vicente Mendes Maciel - nasceu na vila de Quixeramobim, no Ceará, em 1828[6]. Seu pai, segundo o autor, era "comerciante remediado e honrado, proprietário de algumas casas na vila", e lutas de sua família com outras da região não chegaram sequer a atingir o pai, dado que eram "fatos do passado" (NOGUEIRA, 1978, p. 4) - contrariamente ao que, conforme se observará na seção dedicada à análise dos resultados, o Exército Brasileiro contempla em sua versão acerca da guerra. Sua mãe, por sua vez, falecera quando o menino contava seis anos de idade. Adulto, foi caixeiro do comércio de propriedade do pai, do qual assumiu a direção quando o genitor veio a falecer. O filho tinha aí 27 anos, época em que passou a tomar conta das irmãs.

Por ocasião do falecimento do pai, os bens que lhe pertenciam foram absorvidos para o pagamento de dívidas, o qual foi negociado por Antônio mediante garantia hipotecária. Casando-se em 1857, deixou o comércio para se tornar professor, passando daí a caixeiro novamente e, depois, a advogado provisionado, mesma ocasião em que se dá a infidelidade de sua mulher. Consoante Nogueira (1978, p. 5), "daí por diante, muda inteiramente a vida de António Vicente Mendes Maciel", que se desdobraria em duas fases. Na primeira, acentuada pela instabilidade nos serviços e pela contínua mudança de residência e de profissão, encontrar-se-iam os fatores sobre os quais se embasaria a suposição de que, na verdade, Antônio procurava sua ex-mulher e o atual companheiro - o militar João da Mata - para deles se vingar "exemplarmente", conquanto não os tenha nunca encontrado. $\mathrm{Na}$ segunda, quando passa a ganhar a vida de modo estável, ele dá início à exitosa construção de cemitérios, capelas e igrejas, sendo que, conforme Euclides da Cunha (apud Nogueira, 1978), também se acrescentava aí a construção de açudes. Nesta última fase é que o contato com pessoas religiosas o teria influenciado, fazendo-o "voltar à fé primitiva, a de sua formação espiritual" - retomada esta que o faz perdoar aqueles que lhe tinham feito mal e esquecer completamente o passado.

Nesse momento, paulatinamente, vai crescendo o número daqueles que o auxiliavam nessas construções, acompanhando-o "de arraial a arraial e de povoação a povoação":

Imbui-se de tal forma da nova concepção de vida, que executa aquela engenharia com alto espírito religioso. Sua aparência exemplar é de penitente, notada por todos que o têm na maior 
consideração. Não alimenta afeições humanas incompatíveis com a sua vida de peregrino, mas é estimado por quantos lêem a sinceridade em todos os seus atos.

Por tal forma a sua personalidade desperta a atenção geral que, confiantes, muitas pessoas lhe fazem confidências. Dele se aproximam para pedir-lhe conselho e as suas palavras thes servem de lenitivo (NOGUEIRA, 1978, p. 6).

Conforme se vê, pouco a pouco é que se vai delineando a construção da figura de Antônio como "Conselheiro", à medida que também passam a acompanhá-lo espontaneamente aqueles que já tinham sofrido com a politicagem desordenada, com a voracidade do fisco e as arbitrariedades cometidas pela polícia - o que ocorria abundantemente, a ponto de os sertanejos temerem mais as autoridades do que os bandidos. Enxergando as virtudes daquele homem, Nogueira (1978) registra que pedem para ficar em sua companhia, trabalhando consigo naquelas obras. De modo geral, todos almejavam experienciar uma vida honrada. Essas movimentações, porém, passam não somente a chamar atenção, mas a desencadear a oposição de sacerdotes e políticos, sobretudo de padres políticos, surgindo daí os primeiros conflitos, o que culmina com a prisão de Antônio sob a falsa acusação de que teria assassinado a mãe e a mulher. Ante a comprovação de que essas acusações eram fantasiosas, o peregrino retorna aos sertões e ao convívio do povo - "miseráveis populações abandonadas pelo fisco e pelas autoridades" (NOGUEIRA, 1978 , p. 8) -, o que contraria os interesses de autoridades civis e religiosas que se levantam contra ele, perseguindo-o, não obstante a inexistência de qualquer crime do qual se pudesse acusá-lo.

Após a Proclamação da República, Conselheiro (que era monarquista, mas que em momento algum atuava politicamente, no sentido de se insurgir contra o regime de republicano[7]) escolhe Canudos como sendo o tranquilo local no qual almeja se recolher junto ao grande número de trabalhadores que já o acompanhava, seguidos por suas famílias (um total de centenas de pessoas), situando-se numa antiga fazenda de criação na qual todos se instalam em junho de 1893, experimentando um crescimento demográfico de 10.335\% até outubro de 1897 (MARTINS, 2001). E, à parte os pormenores que sucederam a partir daí, "tudo havia de desanuviar-se e Canudos terminaria bem, integrando-se um dia na vida do Estado, por obra do tempo, se não fosse a atitude leviana de certa pessoa" (NOGUEIRA, 1978, p. 15).

No que tange a essa "leviandade", o autor de "Antônio Conselheiro e Canudos" se refere a uma pessoa cuja ação, segundo ele, correspondeu a todos os males que sobrevieram a Canudos, ao Exército Nacional, ao Estado da Bahia e ao próprio País: o jovem juiz de Direito de Juazeiro, dr. Arlindo Leoni, cujas requisições de providências enérgicas enviadas ao governador Luís Viana baseavam-se tão somente na repercussão de boatos acerca de uma suposta invasão de Conselheiro e de seus seguidores à cidade de Juazeiro - invasão esta durante a qual o líder supostamente daria ordem de saque geral ao comércio e se vingaria cabalmente do juiz de Direito da comarca em razão de achaques do passado. $O$ fato, no entanto, era que Conselheiro apenas reunira parte dos canudenses para irem retirar a madeira que seria utilizada no telhado do novo templo que haviam construído, já que a primeira igreja erguida em Canudos não comportava toda a população ali alocada. E, em relação à madeira, ela não seria despachada porque não havia quem a transportasse.

Promovidos os boatos que ganharam contornos cada vez maiores, Canudos experimentou a sua primeira baixa em outubro de 1896 (embora, nesse momento, sequer vislumbrasse a guerra que estaria por vir), quando o governador Luís Viana (que "estava longe e tinha o dever de acreditar no segundo telegrama da autoridade judiciária") atendeu às exigências do juiz alardeador e cem praças do Exército acampados no arraial de Uauá (distante de Canudos por 114 quilômetros) atiraram - afoitos, imprudentes, sem qualquer averiguação nem ordem de comando - contra aquele grupo que caminhava em procissão absorto no propósito de ir retirar a madeira para o telhado do templo. Uma vez surpreendido e em se defendendo do ataque com suas armas grosseiras (facas, foices, pedaços de pau, etc.), tal grupo sofreu a perda de mais de 150 companheiros (fora os feridos), ao passo que o Exército teve dez mortos e 16 feridos (NOGUEIRA, 1978, p. 18-19). Sobre esse episódio, todavia, a força militar assinala que se tratou 
de um "massacre" de 30 homens, o que leva a crer que tenham sido somadas as quantidades de mortos e feridos.

Em carta dirigida ao Presidente da República e ao Ministro da Guerra, o governador Luís Viana registra que a força que combateu em Uauá saqueou todo o povoado, sendo que, desse grupo, houve soldados que, não bastasse o terem assaltado, incendiaram todo o povoado (NOGUEIRA, 1978). Porém, não obstante os registros publicados por Nogueira (jurista, político e professor formado pela Faculdade de Direito da Universidade de São Paulo), baseados em documentos e em obras como a de Euclides da Cunha (2016) e como a do político e escritor Aristides Milton (1902), o Exército Brasileiro (2018, grifo nosso) assinala que, "considerando Canudos sua cidadela, independente do restante do país, seus seguidores paulatinamente começaram a praticar desmandos pelas redondezas, chamando a atenção das autoridades estaduais [...]" e que "O massacre de uma força policial composta de 30 homens [...] levou o governo estadual à ação, deflagrando a chamada Guerra de Canudos, que durante um ano inteiro agitou a nova República, de norte a sul". Consoante a "versão oficial", o início do conflito armado em Canudos deveu-se, portanto, ao "ataque" dos "fanáticos":

O primeiro encontro efetivo entre o Exército e integrantes do grupo de Conselheiro ocorreu
quando um bando de $\mathbf{5 0 0}$ jagunços atacou a força federal em Uauá, a 21 de novembro de
1896. Aos gritos de "Viva Nosso Bom Jesus! Viva Nosso Conselheiro! Viva a Monarquia!", os
fanáticos lançaram-se com destemor contra a tropa entrincheirada nas casas. Inferiorizados
numericamente, os soldados valiam-se de seu melhor armamento. Impossibilitados de obter um
resultado satisfatório com as armas de fogo, os místicos, em rasgo de heroísmo demencial,
lançaram-se ao assalto utilizando armas brancas, com incrível ferocidade, encontrando pela
frente uma tropa destemida que após quatro horas de luta lhes causou a perda de 150 homens,
fazendo esmorecer o seu ímpeto e, por fim, provocando a retirada dos insurretos. Ao avaliar
sua situação em material e pessoal, considerando o potencial humano de Canudos, o Tenente
Pires Ferreira julgou melhor regressar a Juazeiro, o que foi feito após o sepultamento dos mortos.
Encerrara-se a primeira participação do Exército na luta contra os fanáticos de Antônio
Conselheiro. Ficara evidenciada a disposição de luta dos jagunços, que no futuro evitariam o
embate a peito aberto, preferindo a técnica de posições protegidas e de ataques furtivos
(EXÉRCITO BRASILEIRO, 2018, grifos nossos).

Estava assim declarado o início da Guerra de Canudos, sendo que, nela, "[...] Os canudenses, sob a chefia de Antônio Conselheiro, usaram do sagrado direito de legítima defesa de suas pessoas e bens" (NOGUEIRA, 1978, p. 21).

Como é sabido, “[...] Poderosas expedições foram organizadas contra o reduto, algumas com reforços de 'tropas estrangeiras'. [...]” (MACEDO; MAESTRI, 2004). Acerca dessas “poderosas expedições” tem-se, por exemplo, a obra de Araripe, na qual, sob a perspectiva militar, o autor visa a "colher ensinamentos e reparar injustiça, internacional ou não, que se originou da monumental obra de Euclides da Cunha" (ARARIPE, 1895, p. 8)". Todavia, não obstante todos os ataques governistas e a ideia com que os jornais excitavam os republicanos, divulgando que "os fanáticos" do sertão nordestino pretendiam "restaurar a monarquia" e que Antônio Conselheiro era disso o responsável (NOGUEIRA, 1978) [8], Canudos não se rendeu, resistindo até o seu último combatente, com o término da guerra a 5 de outubro de 1897.

\section{A História como ciência e a Guerra de Canudos na História Militar}

Conforme é possível verificar com base na contextualização apresentada na seção anterior, as versões publicadas por Nogueira (1978) a partir dos manuscritos de Antônio Conselheiro e os excertos publicados pelo Exército Brasileiro são contraditórias, conquanto tenham em comum a condição de se referirem a um mesmo evento e, portanto, de estarem reproduzindo os fatos tais como eles teriam verdadeiramente ocorrido. Entretanto, como admitir que, na condição de ciência, a História pudesse comportar narrativas tão dissidentes acerca de um mesmo acontecimento, sem a adoção de uma metodologia própria, mediante a qual a reconstrução dos fatos não estivesse atrelada à mobilização de memórias? 
No que diz respeito às contradições muitas vezes apontadas em relação ao mesmo evento histórico, Parente e Sanches (2009, p. 46) pontuam que "os percursos que nos levam do presente ao passado através da história ou da memória não são os mesmos". Para os autores, a diferença entre uma e outra perspectiva residiria no fato de que, em relação à história, o conhecimento do passado resultaria da construção de um conhecimento viabilizado cientificamente, o que implica, portanto, a elaboração de uma pesquisa científica na qual a metodologia científica se aplica. Em relação à memória, no entanto, o conhecimento do passado não implicaria a obrigatoriedade do percurso científico na construção do conhecimento: a memória se instituiria "a partir de astúcias que envolvem a valorização de qualidades e personagens, a incorporação de valores ou feitos e, mesmo, a tática do esquecimento, quando lhe for conveniente" (PARENTE; SANCHES, 2009, p. 48). Quanto a essas astúcias que envolvem a atribuição e/ou a mobilização de valores, estes são definidos por grupos - ou até mesmo pela nação - em momentos históricos diferentes, podendo, portanto, sofrer variações a cada período, uma vez que, ao longo da História, as motivações ideológicas, religiosas, políticas, doutrinárias, coletivas, etc. também se sucedem. Daí, por conseguinte, o motivo pelo qual as versões voltadas à reprodução do conflito armado em Canudos também sofrem variações. E é ainda nesse sentido que Jenkins explica que passado e história são coisas diferentes:

[...] o passado e a história não estão unidos um ao outro de tal maneira que se possa ter uma, e apenas uma leitura histórica do passado. O passado e a história existem livres um do outro; estão muito distantes entre si no tempo e no espaço. Isso porque o mesmo objeto de investigação pode ser interpretado diferentemente por diferentes práticas discursivas [...], ao mesmo tempo que, em cada uma dessas práticas, há diferentes leituras interpretativas no tempo e no espaço [...] (JENKINS, 2001, p. 23-24, grifo nosso).

Sob esse entendimento, nos três documentos que constituem o corpus desta pesquisa - e a exemplo da amostra possibilitada pela breve contextualização acerca da Guerra de Canudos -, parte-se já do pressuposto de que, embora o conflito seja o objeto de investigação comum a todos, sua interpretação decorre de práticas discursivas diferentes, uma vez que, para fins de análise, encontram-se relacionados o discurso de uma força armada (Exército Brasileiro), o discurso de um historiador renomado (José Calasans) e o discurso de um jornalista reconhecido (Otávio Frias Filho), cada qual tendo sido produzido em um momento histórico específico. No caso do excerto extraído do site do Exército Brasileiro, não consta a data de elaboração ou publicação do texto; no caso de Calasans, celebrava-se o centenário de morte do líder de Canudos; no caso de Frias Filho, as comemorações se davam em torno do centenário do desfecho da Guerra.

Assim, haja vista o momento histórico em que cada um desses locutores se situa, bem como os coletivos a que pertencem e que representam, nos quais mobilizam as motivações que lhes são próprias, é que: a publicação do Exército (2018) discorre a respeito da figura de um Antônio Conselheiro não heroico, cujos seguidores eram "fanáticos" e cujas ações culminaram com a guerra; a publicação de Calasans (1997) discorre a respeito da figura de um Antônio Conselheiro cujos feitos podem ser considerados "milagres", cujos seguidores eram pessoas de fé e cujas ações não foram bem compreendidas; e, a publicação de Frias Filho (1997), a respeito de "revoltosos" que, na verdade, não pretendiam subverter a ordem, mas compunham uma comunidade que "requeria ser integrada, não suprimida".

No que concerne à construção da memória do passado, a qual confere um sentido àquilo que se entende como sendo o próprio passado e uma apreciação de ordem moral às figuras e aos feitos que ele contempla, Parente e Sanches (2009) a distinguem a partir de três diferentes níveis de entendimento: (i) a memória individual, cuja lembrança do passado está inserida em acontecimentos coletivos; (ii) a memória coletiva, produzida a partir de um grupo dentro da sociedade ou de uma determinada cultura; e (iii) a memória social, que transcende a memória coletiva quando é aceito um conjunto de memórias, incluindo seus valores e crenças. Neste último caso, portanto, surge a construção de uma memória nacional que transcende as memórias regionais, sendo que tanto a memória coletiva quanto a memória social influenciam na formação das identidades coletivas que constituem uma nação. 
Conquanto nem sempre seja possível estabelecer uma convergência entre a memória histórica e o conhecimento histórico (isto porque, ao contrário da história, a memória não tem, necessariamente, um compromisso com a veracidade dos fatos nem é trazida à tona de maneira uniforme e sistemática), é a memória - constitutivamente subjetiva - que se apresenta como um importante fator na construção da consciência nacional, agregando grupos heterogêneos que, em torno de um passado comum, formam uma nação.

Tomada essa relação (nem sempre convergente) entre história e memória, bem como entre históriamemória-jornalismo, é que, ao se concentrar na análise de duas publicações do jornal Folha de S.Paulo acerca da Guerra de Canudos por ocasião do seu centenário, neste artigo parte-se do entendimento de que o jornal (e, sobretudo, um jornal de grande visibilidade nacional) se configura como um espaço no qual a memória (re)produzida é capaz de influenciar na (re)construção das memórias individual, coletiva e social acerca desse mesmo evento militar, lembrando ainda que a construção das memórias coletiva e social influencia na formação da identidade coletiva que constitui a própria nação.

\section{Entre o "oficial" e o histórico: o que dizem o Exército e a Folha de S.Paulo}

Para viabilizar mais fácil comparativo entre as apreciações de cada enunciador neste primeiro momento, optou-se pela elaboração de um quadro no qual a primeira parte do texto disponibilizado no site do Exército Brasileiro (doravante, "EB") ("Origens") fosse fielmente reproduzida e classificada em três momentos: a) em relação às origens de Conselheiro e à religião por ele professada; b) em relação ao seu surgimento como líder e como Antônio Conselheiro, (re)conhecido como tal; e c) em relação a Conselheiro associado aos seus seguidores e ao início da guerra. Tal classificação orientou a seleção dos excertos da publicação de Calasans (1997), da qual também foram reproduzidos trechos literais.

Quadro 1 - Fiel reprodução dos excertos do EB e de Calasans para efeito comparativo

\begin{tabular}{|c|c|c|}
\hline TÓPICOS & Versão oficial - EB & Versão de Calasans / Folha de S.Paulo \\
\hline $\begin{array}{c}\text { a) Das } \\
\text { origens } \\
\text { familiares de } \\
\text { Antônio } \\
\text { Maciel à } \\
\text { religião } \\
\text { professada } \\
\text { por ele }\end{array}$ & $\begin{array}{l}\text { 1a. Antônio Vicente Mendes Maciel, nascido } \\
\text { em Quixeramobim, Ceará, em 1826, } \\
\text { 1b. era membro da famosa família dos Maciéis, } \\
\text { sempre em luta com a dos Araújos - dois clãs } \\
\text { cujas violências ensangüentaram e mantiveram } \\
\text { em permanente intranqüilidade o interior do } \\
\text { Estado. } \\
\text { 2. Traído pela mulher, Brasilina de Lima, fez } \\
\text { voto de castidade e, dedicando-se à fé da } \\
\text { crença católica, tornou-se fanático, } \\
\text { embrenhando-se pelo sertão em constantes } \\
\text { peregrinações e pregações. }\end{array}$ & $\begin{array}{l}\text { 1a. Antônio Vicente Mendes Maciel, Conselheiro de } \\
\text { alcunha, também apelidado Santo Antônio dos Mares, } \\
\text { Santo Antônio Aparecido, Santo Conselheiro, Bom } \\
\text { Jesus Conselheiro, Nosso Bom Jesus, era cearense e } \\
\text { nasceu na Vila de Santo Antônio de Quixeramobim, a } 13 \text { de } \\
\text { março de 1830; } \\
\text { 1b. Não foi uma criança pobre, os problemas de sua infância } \\
\text { foram outros: orfandade aos quatro anos, maltratos da } \\
\text { madrasta, segunda mulher de Vicente, notícias alarmantes } \\
\text { das lutas dos seus parentes pelo lado paterno com as } \\
\text { famílias dos Araújos e Veras. [...] } \\
\text { 2a. Seu pai, analfabeto, procurava dar ao primogênito uma } \\
\text { boa instrução. Aprendeu a ler, escrever e contar. Sua letra } \\
\text { era firme e seu texto claro. Andou estudando latim, } \\
\text { enxertando frases da língua de Horácio nos seus longos } \\
\text { "conselhos", geralmente baseados na Bíblia sagrada, que } \\
\text { conhecia razoavelmente. Era um "biblado", declarou um } \\
\text { velho sertanejo ao antropólogo Renato Ferraz. Sabendo } \\
\text { latim e citando o "livro dos livros", podia enfrentar os } \\
\text { vigários sertanejos. Seus conselhos eram longos, suas } \\
\text { conversas "tête-à-tête", rápidas. Voz baixa, alterada nos anos } \\
\text { de sua pregação anti-republicana, quando combatia o novo } \\
\text { regime, o casamento civil, a secularização dos cemitérios, a } \\
\text { maçonaria, os protestantes. Pessoalmente falava aos } \\
\text { seguidores com cordialidade, a todos tratando de irmãos. } \\
\text { Por seu turno, deviam chamá-lo "meu pai". } \\
\text { 2b. Deixando Quixeramobim, após o malogro comercial, já } \\
\text { casado com Brasilina, com quem era aparentado, tentou, } \\
\text { sem bom exxito, várias atividades: magistério, comércio, } \\
\text { advocacia, tudo em nível auxiliar. O casamento não deu } \\
\text { certo, por infidelidade da mulher, que lhe dera alguns }\end{array}$ \\
\hline
\end{tabular}




\begin{tabular}{|c|c|c|}
\hline & & $\begin{array}{l}\text { filhos, de nomes e destinos desconhecidos. O desenlace } \\
\text { matrimonial deu origem à tremenda estória: ele matara a } \\
\text { mulher infiel e a mãe denunciadora. A história apurou que o } \\
\text { Conselheiro ficara órfão aos quatro anos... }\end{array}$ \\
\hline $\begin{array}{c}\text { b) } \mathrm{Da} \\
\text { atuação de } \\
\text { Antônio } \\
\text { Maciel como } \\
\text { líder: o } \\
\text { surgimento } \\
\text { de Antônio } \\
\text { Conselheiro }\end{array}$ & $\begin{array}{l}\text { 3. Logo tornou-se adorado pelas populações } \\
\text { incultas do interior. Ia sempre seguido de um } \\
\text { grupo de adeptos, de ambos os sexos, através } \\
\text { dos sertões de Pernambuco, do Ceará, do Piauí, } \\
\text { de Sergipe e da Bahia. } \\
\text { 4. Ora parando em fazendas, de cujos } \\
\text { proprietários exigia alimentação e pousada } \\
\text { para si e seus seguidores, ora trabalhando como } \\
\text { pedreiro no levantamento de muros em } \\
\text { cemitérios ou em pequenas barragens de } \\
\text { açudes, pouco a pouco seu prestígio foi } \\
\text { crescendo e com ele o número e a disposição } \\
\text { de seus sequazes. } \\
\text { 5. E, com o nome de Antônio "Conselheiro", } \\
\text { começou a ficar conhecido. }\end{array}$ & $\begin{array}{l}\text { 3. Duas fases na vida conselheirista. Em 1874, quando } \\
\text { chegou ao centro das Províncias de Bahia e de Sergipe, o } \\
\text { Conselheiro, com prestígio crescente, peregrinou. [... Era } \\
\text { apenas um peregrino, acompanhado de numeroso séquito; } \\
\text { pequenos agricultores, negros } \mathbf{1 3} \text { de Maio, caboclos de } \\
\text { aldeamentos, gente sem recursos, doentes. Eram } \\
\text { andejos. Paravam por algum tempo para fazer obras. } \\
\text { 4. [Conselheiro] Construiu e restaurou capelas, levantou } \\
\text { muros de cemitérios, abriu tanques d'água, fez "milagres". }\end{array}$ \\
\hline $\begin{array}{l}\text { c) Antônio } \\
\text { Conselheiro } \\
\text { associado a } \\
\text { seus } \\
\text { seguidores e } \\
\text { ao início da } \\
\text { Guerra }\end{array}$ & $\begin{array}{l}\text { 6. Chegando a Canudos, no interior da Bahia, } \\
\text { em 1893, decidiu fixar raízes; } \\
\text { 7. Iniciou-se então o crescimento } \\
\text { desordenado do pequeno arraial, em } \\
\text { conseqüência do afluxo, em número cada vez } \\
\text { maior, de fanáticos e de místicos, atraídos } \\
\text { pela fama dos milagres de Conselheiro; } \\
\text { 8. Considerando Canudos sua cidadela, } \\
\text { independente do restante do país, seus } \\
\text { seguidores paulatinamente começaram a } \\
\text { praticar desmandos pelas redondezas, } \\
\text { chamando a atenção das autoridades } \\
\text { estaduais; } \\
\text { 9. O massacre de uma força policial } \\
\text { composta de } 30 \text { homens sob o comando do } \\
\text { Capitão Virgílio Pereira de Almeida, em } \\
\text { Masseté, levou o governo estadual à ação, } \\
\text { deflagrando a chamada Guerra de Canudos, } \\
\text { que durante um ano inteiro agitou a nova } \\
\text { República, de norte a sul; } \\
\text { 10. Como parecia ser um fenômeno religioso, } \\
\text { o Presidente do Estado, Luís Vianna, enviou a } \\
\text { Canudos Frei João Evangelista do Monte } \\
\text { Marciano e Frei Caetano de São Leo, como } \\
\text { observadores (1895), de nada adiantando as } \\
\text { suas palavras amenas. Trouxeram, porém, } \\
\text { um falso retrato de Conselheiro: inimigo da } \\
\text { República. }\end{array}$ & $\begin{array}{l}\text { 6. e 9. Em 1893, o quadro se modificou. Depois do choque } \\
\text { de Masseté, quando os conselheiristas desbarataram } \\
\text { uma força policial e o governo anunciou a remessa de } \\
\text { novas tropas, Antônio Vicente se estabeleceu em Canudos, } \\
\text { povoado antigo à margem do rio Vazabarris, que conhecia } \\
\text { havia muito tempo. Rebatizou a localidade, dando-lhe o } \\
\text { nome de Belo Monte. } \\
\text { 8. Criou um clima de tranquilidade local. Respeitavam-no. } \\
\text { Seu monarquismo era utopia. De vários pontos do sertão } \\
\text { apareciam os conselheiristas que iam viver, não raro } \\
\text { precariamente, numa terra paradisíaca... Caminhavam para } \\
\text { lá movidos pela fé. Queriam morar ali, sem pensar em } \\
\text { conquistar novas terras. Nem restaurar a monarquia. } \\
\text { 10. Cá de fora, não entenderam assim. Interesses } \\
\text { políticos e patrimoniais deram novos rumos e destino } \\
\text { sangrento ao sertão do Conselheiro. Morreram milhares de } \\
\text { sertanejos, denominados pejorativamente de jagunços, de } \\
\text { bandidos, malfeitores. O maior equívoco da história } \\
\text { nacional. O Santo Conselheiro, que morreu a } 22 \text { de } \\
\text { setembro de } 1897 \text {, faz um século, diziam os sobreviventes } \\
\text { da guerra, só pregava o bem, a salvação das almas. }\end{array}$ \\
\hline
\end{tabular}

Fonte: EXÉRCITO BRASILEIRO (2018); CALASANS (1997) (grifos meus).

No tópico "a", intitulado "Das origens familiares de Antônio Maciel à religião professada por ele", conforme se pode observar em 1a., embora exista concordância quanto ao local do nascimento de Antônio Conselheiro, não há consenso no que se refere ao ano - que, segundo o Exército, seria o de 1826; já segundo o historiador, 1830. Além disso, em 1b. também se verifica um “juízo de valor” de um lado em oposição a um registro aparentemente isento de outro: de acordo com o EB, Conselheiro pertencia a uma "famosa família" que não apenas estaria sempre em luta com a dos "Araújos", mas cuja violência "ensanguentara e mantivera em permanente intranquilidade o interior do Estado". Por isso mesmo, essa família poderia ser referenciada como "clã", cujo sentido figurado, consoante o Houaiss, corresponde a "facção" - termo este que, por sua vez, conforme o mesmo dicionário, pode ser tomado 
como "bando ou partido insurreto". Já de acordo com Calasans, as "notícias alarmantes das lutas dos seus parentes pelo lado paterno com as famílias dos Araújos e Veras" correspondiam, simplesmente, aos "problemas de sua infância". E "Veras", a propósito, não é uma família mencionada na versão do EB.

No item 2 (que, na terceira coluna, foi dividido em 2a. e em 2b. para que se pudesse estabelecer o necessário paralelo entre as duas versões), nota-se, na introdução do EB à fé praticada pelo líder canudense, a proposição de uma relação de causa e efeito: "Traído pela mulher [...] fez voto de castidade", de modo que daí poderia se inferir que a "dedicação à fé da crença católica" não resultaria, necessariamente, de uma "vocação" (o que se considera o habitual em relação àqueles que optam pela carreira religiosa), mas, possivelmente, de uma "frustação" no seu relacionamento amoroso. No mais, dado que, em se "dedicando à fé da crença católica", Conselheiro teria se tornado "fanático", a "dedicação" de Antônio Vicente teria suscitado algo ruim, uma vez que, entre outras aplicações, o termo "fanático" pode implicar uma valorização negativa em torno de um indivíduo no qual se manifesta algum tipo de excesso (para o Houaiss, por exemplo, "fanatismo" corresponde a um "zelo religioso obsessivo que pode levar a extremos de intolerância”).

De acordo com Calasans, por sua vez, a dedicação à fé católica não seria decorrente da "traição" da esposa ("traição", a propósito, à qual o Professor se refere por meio da palavra "infidelidade", que sugere, discursivamente, um outro posicionamento). Ocorre que, antes desse evento, Conselheiro já seria um "biblado" e sua atuação junto à população já estaria bem delineada. Quanto ao casamento que "não deu certo", o intelectual nada acrescenta por consequência, exceto a história que se criou sobre Conselheiro ter matado "a mulher infiel" - história que não se comprova, conforme o autor sugere quando se refere ao "assassinato" que Conselheiro também teria cometido contra a mãe, quando, na verdade, ficara órfão aos quatro anos de idade.

No item 3, referente ao tópico "b) Da atuação de Antônio Maciel como líder: o surgimento de Antônio Conselheiro", verifica-se um novo juízo de valor por parte do EB: o líder tornara-se "adorado pelas populações incultas do interior". Assim, é de se presumir qual seria a concepção de "cultura" por parte dessa formação discursiva, posto que as "populações incultas" a que a força militar se refere corresponde, na verdade, aos "pequenos agricultores, negros 13 de Maio, caboclos de aldeamentos, gente sem recursos, doentes", assim especificados por Calasans, que apenas os caracterizou como "andejos", que "paravam por algum tempo para fazer obras" - sem juízo de valor.

Cumpre observar ainda que, no que diz respeito às "populações incultas", Conselheiro tornou-se "adorado" por elas, o que sugere outra apreciação aí implícita por parte do EB: tomando a sua própria cultura como referência e designando como "inculto" o povo canudense (numa "ausência de cultura" que corresponderia a uma "ignorância"), essa "adoração" (remetendo ao sentido de "veneração", "idolatria", em oposição à "razão") poderia ser uma consequência da própria "falta de conhecimento". O historiador, por sua vez, não se utiliza dos mesmos termos: antes, registra que Conselheiro peregrinou com "prestígio crescente", "acompanhado de numeroso séquito".

Logo adiante, o Exército também assinalará algo similar em "pouco a pouco seu prestígio foi crescendo"; contudo, por partir da ideia de que se tratava de uma "população inculta", o sentido do "prestígio" aí implicado não seria exatamente o mesmo que se pode deduzir do texto de Calasans. Desta forma é que, analisando-se o vocabulário aplicado pelo EB e pelo convidado da Folha, depreende-se uma significativa diferença no posicionamento discursivo de cada um, dada a distinção que existe entre ser "adorado" (o que não exige, necessariamente, o exercício de um senso crítico por parte daquele que "adora", "idolatra", "venera") e ser "prestigiado" (o que pressupõe o reconhecimento das qualidades de alguém ou de alguma coisa que infunde admiração, respeito (HOUAISS), sendo que, para que essas qualidades sejam reconhecidas, pressupõe-se a mobilização de um senso crítico). Portanto, o discurso de cada um dos lados mantém a coerência no seu parecer: para o EB, dada a "ausência de cultura" daquela população, esta só podia "adorar" o renomado líder; para o Professor, todavia, aquele "numeroso séquito" (cuja 
ausência de recursos não configurava uma "incultura") conferia "prestígio" a Antônio, reconhecendo seus feitos.

A propósito dos feitos de Conselheiro, nova observação deve ser contemplada no que tange ao quadro elaborado para efeito comparativo: segundo o EB, o líder e seus seguidores "ora paravam em fazendas de cujos proprietários exigiam alimentação e pousada", informação da qual se pode deduzir que se tratasse de alguma espécie de "abuso" (afinal, por que esses fazendeiros deveriam "financiar" esse grupo em suas andanças? e qual o direito que eles teriam de "exigir" qualquer coisa?). De acordo com o especialista na Guerra de Canudos, porém, eles "paravam por algum tempo para fazer obras" - então, não é que parassem para "exigir" qualquer alguma coisa, tampouco para "descansar". No mais, ambos os locutores concordam quanto a Conselheiro ter levantado muros de cemitérios e ter aberto barragens de açudes/tanques d'água, conquanto não cheguem à mesma conclusão. Nas palavras do EB um pouco mais adiante, no item 7, era cada vez maior o afluxo do número de "fanáticos" e de "místicos" atraídos "pela fama dos milagres de Conselheiro"; já nas palavras de Calasans, Conselheiro não fez "fama": levando em conta seus feitos naquele contexto, Conselheiro fez "milagres".

No item 5, o EB acrescenta que, a partir da sua atuação, o líder começou a ficar conhecido com o nome de Antônio "Conselheiro". Nota-se que "Conselheiro" é registrado entre aspas, sugerindo algum sentido aí "em suspenso", que pode ser a marca de quem não se identifica com a alcunha atribuída a ele e que, portanto, sinalizaria que essa é uma palavra que não pertence à sua grade semântica, mas da qual esse enunciador se apropria manifestando o seu distanciamento daquilo que ela significa potencialmente. Em 1a., no entanto, note-se que Calasans não apenas não usa aspas para se referir a Conselheiro, como ainda o apresenta assinalando outras alcunhas por meio das quais o líder também se fazia conhecer: "Santo Antônio dos Mares", "Santo Antônio Aparecido", "Santo Conselheiro", "Bom Jesus Conselheiro" e "Nosso Bom Jesus". Ao não se utilizar de aspas para fazê-lo (aspas aqui utilizadas em função da reprodução do original), o historiador não se "distancia", podendo-se daí deduzir a sua anuência com os modos pelos quais Conselheiro era interpelado (anuência que se confirma, aliás, quando, no item 8, ele se refere a essa figura histórica como "o Santo Conselheiro").

Por fim, na última linha do quadro - "c) Antônio Conselheiro associado a seus seguidores e ao início da Guerra" -, outras importantes passagens devem ser examinadas, a começar pelas razões que culminaram com o início da Guerra de Canudos. Isto porque, conforme se verifica na coluna em que se reproduz o texto do EB, dois fatos interligados teriam suscitado a intervenção militar: 1) os "desmandos" praticados pelos seguidores de Conselheiro, que teriam "chamado atenção das autoridades estaduais", e 2) o "massacre" de uma força policial em Masseté, que "levou o governo estadual à ação".

Aqui, cumpre destacar que, em se reportando às "origens", a publicação disponibilizada pelos militares seguiu a ordem cronológica dos acontecimentos, de modo que, em relação ao trecho agora mencionado, tem-se que Antônio Conselheiro primeiramente se estabeleceu em Canudos (onde "decidiu fixar raízes") e que, depois, ocorreram os desmandos dos seus seguidores e o referido "massacre". Já na coluna que reproduz o artigo de Calasans, Conselheiro se estabeleceu em Canudos depois do "choque de Masseté", sendo que os conselheiristas não "massacraram" a força policial: "desbarataram-na". Além disso, no que se refere aos "desmandos" da população, o historiador constrói uma outra imagem: "Caminhavam para lá movidos pela fé. Queriam morar ali, sem pensar em conquistar novas terras. Nem restaurar a monarquia", isto é, parecia se tratar de uma comunidade pacífica, que não pretendia "incomodar". Por essa razão, é possível depreender, inclusive, um tom de lamento na introdução do parágrafo final do Professor: "Cá de fora, não entenderam assim", confirmando-se o seu posicionamento - agora explícito - a respeito da figura de Conselheiro e do que, afinal, sintetiza essa guerra: "O maior equívoco da história nacional". Quanto ao Exército, verifica-se que, ainda que a criação da imagem de Antônio Conselheiro como "inimigo da República" seja atribuída aos freis João Evangelista do Monte Marciano e Caetano de São Leo, não há, nesse equívoco, a manifestação de um lamento. Se é verdade que a força militar 
reconhece que aquele era um falso retrato de Conselheiro, não é menos verdade que, de sua parte, não é verbalizado qualquer pesar ou reconsideração nesse sentido.

Assim, com base na análise realizada até aqui, constata-se que, à exceção da concordância quanto à atuação de Conselheiro como pedreiro no levantamento de muros em cemitérios e na abertura de tanques de água (quarta linha da segunda e terceira colunas do Quadro 2), todos os demais pontos divergem entre os posicionamentos analisados, não obstante todos eles "dialogarem" entre si, conforme sintetizou-se a seguir:

Quadro 2: Síntese dos posicionamentos depreendidos do EB e de José Calasans/Folha de S.Paulo

\begin{tabular}{|c|c|c|}
\hline TÓPICO & POSICIONAMENTO DO EB & $\begin{array}{l}\text { POSICIONAMENTO DE CALASANS } \\
(\text { FOLHA) }\end{array}$ \\
\hline \multirow{6}{*}{$\begin{array}{l}\text { QUEM ERA } \\
\text { CONSELHEIRO } \\
\text { E QUAL A SUA } \\
\text { ATUAÇÃO }\end{array}$} & - um fanático & $\begin{array}{l}\text { - apenas um peregrino, acompanhado de numeroso } \\
\text { séquito }\end{array}$ \\
\hline & - alguém que tinha fama de milagreiro & • alguém que fez "milagres" \\
\hline & $\begin{array}{l}\text { - alguém que parava em fazendas e exigia } \\
\text { alimentação e pousada para si e seus seguidores }\end{array}$ & - alguém que criou um clima de tranquilidade local \\
\hline & $\begin{array}{l}\text { - alguém que trabalhava como pedreiro no } \\
\text { levantamento de muros em cemitérios } \\
\text { - alguém que trabalhava em pequenas } \\
\text { barragens de açudes }\end{array}$ & $\begin{array}{l}\text { - alguém que construiu e restaurou capelas } \\
\text { - alguém que levantou muros de cemitérios } \\
\text { - alguém que abriu tanques de água }\end{array}$ \\
\hline & $\begin{array}{l}\text { - alguém cujo prestígio foi crescendo pouco a } \\
\text { pouco } \\
\text { • alguém que começou a ficar conhecido pelo } \\
\text { nome de Antônio "Conselheiro" }\end{array}$ & $\begin{array}{l}\text { - alguém com prestígio crescente } \\
\text { - era Antônio Vicente Mendes Maciel, Conselheiro } \\
\text { de alcunha, também apelidado Santo Antônio dos } \\
\text { Mares, Santo Antônio Aparecido, Santo Conselheiro, } \\
\text { Bom Jesus Conselheiro, Nosso Bom Jesus } \\
\text { - já era um "biblado", capaz de enfrentar os vigários } \\
\text { sertanejos }\end{array}$ \\
\hline & $\begin{array}{l}\text { - alguém que foi falsamente retratado como } \\
\text { inimigo da República }\end{array}$ & $\begin{array}{l}\text { - o Santo Conselheiro, que, conforme diziam os } \\
\text { sobreviventes da guerra, só pregava o bem, a } \\
\text { salvação das almas }\end{array}$ \\
\hline \multirow{3}{*}{$\begin{array}{l}\text { QUEM ERAM } \\
\text { SEUS } \\
\text { SEGUIDORES }\end{array}$} & $\begin{array}{l}\text { - a população inculta do interior } \\
\text { - fanáticos e místicos }\end{array}$ & $\begin{array}{l}\text { - pequenos agricultores, negros } 13 \text { de Maio, caboclos } \\
\text { de aldeamentos, gente sem recursos, doentes - } \\
\text { andejos }\end{array}$ \\
\hline & $\begin{array}{l}\text { - aqueles que consideravam Canudos sua cidadela, } \\
\text { independente do restante do País }\end{array}$ & $\begin{array}{l}\text { - aqueles que paravam por algum tempo para fazer } \\
\text { obras } \\
\text { - conselheiristas que caminhavam para Canudos } \\
\text { movidos pela fé, sem pensar em conquistar novas } \\
\text { terras nem em restaurar a monarquia }\end{array}$ \\
\hline & $\begin{array}{l}\text { - aqueles cujos desmandos praticados pelas } \\
\text { redondezas começaram a chamar atenção das } \\
\text { autoridades estaduais }\end{array}$ & - conselheiristas que desbarataram uma força policial \\
\hline \multirow{4}{*}{$\begin{array}{l}\text { O QUE TERIA } \\
\text { EXPLICARIA } \\
\text { INTERVENÇÃO } \\
\text { MILITAR? }\end{array}$} & $\begin{array}{l}\text { - o afluxo, em número cada vez maior, de fanáticos } \\
\text { e de místicos, o que resultou no crescimento } \\
\text { desordenado do pequeno arraial }\end{array}$ & \multirow[t]{4}{*}{ - interesses políticos e patrimoniais } \\
\hline & $\begin{array}{l}\text { - os desmandos que os seguidores praticavam nas } \\
\text { redondezas }\end{array}$ & \\
\hline & $\begin{array}{l}\text { - o massacre de uma força policial composta de } 30 \\
\text { homens }\end{array}$ & \\
\hline & $\begin{array}{l}\text { - o falso retrato de Conselheiro como inimigo da } \\
\text { República }\end{array}$ & \\
\hline
\end{tabular}

Fonte: EXÉRCITO BRASILEIRO (2018); CALASANS (1997).

Além disso, para se interpretar o posicionamento de Calasans - que, indiretamente, corresponderia ao posicionamento do próprio Jornal no qual ele foi convidado a escrever -, foi preciso relacionar o seu artigo a um dos outros enunciados sobre os quais ele se apoia (o posicionamento do EB sobre os mesmos fatos), atestando-se o postulado teórico de Maingueneau (2015, p. 28): para interpretar o menor enunciado, "é necessário relacioná-lo, conscientemente ou não, a todos os tipos de outros enunciados sobre os quais ele se apoia de múltiplas maneiras". 


\section{José Calasans e Otávio Frias Filho: dois enunciadores, um único olhar sobre a guerra}

Embora a possibilidade de se tomar o posicionamento de Calasans como o posicionamento do próprio jornal pelo qual ele foi convidado a se manifestar sobre Conselheiro e a Guerra de Canudos em si, entendeu-se a necessidade de se correlacionar a sua apreciação ao artigo de opinião produzido por Otávio Frias Filho por ocasião do centenário do desfecho da Guerra de Canudos. Assim, sob o propósito de novamente viabilizar mais fácil comparativo entre as apreciações de cada enunciador, elaborou-se um novo quadro, investigando-se, dessa forma, se o posicionamento do historiador corresponderia, efetivamente, ao posicionamento do próprio veículo, dado que Frias Filho era o então diretor de redação do veículo. Nesse quadro, foram recuperados os excertos nos quais se vislumbrou o diálogo mais direto entre as duas versões:

Quadro 3: Fiel reprodução dos excertos da própria Folha para efeito comparativo

\begin{tabular}{|c|c|c|}
\hline & EXCERTOS DO ARTIGO DE CALASANS & EXCERTOS DO ARTIGO DE FRIAS FILHO \\
\hline 1. & $\begin{array}{l}\text { [...] Era apenas um peregrino, acompanhado de numeroso séquito; pequenos } \\
\text { agricultores, negros } 13 \text { de Maio, caboclos de aldeamentos, gente sem recursos, } \\
\text { doentes. Eram andejos. [...] }\end{array}$ & $\begin{array}{l}{[\ldots . .] \text { Uma epopéia é normalmente a narrativa de um povo }} \\
\text { que se forma como nação na guerra contra o inimigo } \\
\text { estrangeiro. No caso da expedição [...], o inimigo é a própria } \\
\text { população ou parte substancial dela, apartada do restante } \\
\text { não por uma linha geográfica, como na guerra civil } \\
\text { americana, mas social. }\end{array}$ \\
\hline 2. & $\begin{array}{l}\text { [...] Seu monarquismo era utopia. De vários pontos do sertão apareciam os } \\
\text { conselheiristas que iam viver, não raro precariamente, numa terra } \\
\text { paradisiaca... Caminhavam para lá movidos pela fé. Queriam morar ali, } \\
\text { sem pensar em conquistar novas terras. Nem restaurar a monarquia. }\end{array}$ & $\begin{array}{l}\text { [...] Do lado dos revoltosos, outra estranheza: em vez de } \\
\text { subverter a ordem para substituí-la por uma nova, como é } \\
\text { praxe entre os revoltosos de todos os tempos, a rebelião } \\
\text { de Canudos pretendia, ao contrário, restaurar uma } \\
\text { ordem anterior, tradicional, ela sim subvertida pela } \\
\text { proclamação da República no Rio de Janeiro. } \\
\text { A simbologia ultrapassou de longe o episódio tributário, } \\
\text { insuflada desde o início pela imprensa jacobina da } \\
\text { capital, que acusava o partido monarquista de estar } \\
\text { por trás da revolta. [...] }\end{array}$ \\
\hline 3. & $\begin{array}{l}\text { [...] Cá de fora, não entenderam assim. Interesses politicos e patrimoniais } \\
\text { deram novos rumos e destino sangrento ao sertão do Conselheiro. Morreram } \\
\text { milhares de sertanejos, denominados pejorativamente de jaguncos, de } \\
\text { bandidos, malfeitores. O maior equivoco da bistória nacional. }\end{array}$ & $\begin{array}{l}\text { [...] Opressores são civilizados, oprimidos são } \\
\text { retrógrados, a sociedade como um todo parece de } \\
\text { cabeça para baixo ou deformada por efeito de alguma } \\
\text { perversão interna. O próprio livro de Euclides da Cunha é } \\
\text { um libelo contra essa guerra, que ele chama de crime da } \\
\text { nacionalidade, pois Canudos requeria ser integrada, não } \\
\text { suprimida. Intoxicado, porém, pela atmosfera intelectual } \\
\text { da época, quando estavam em voga as mais abstrusas e } \\
\text { servis teorias do "racismo científico", o autor da epopéia } \\
\text { identifica o elemento perverso não na estrutura econômica, } \\
\text { mas numa mirabolante patologia em que a mestiçagem } \\
\text { enfraquece as raças "superiores", tornando-as "histéricas". } \\
\text { [...] }\end{array}$ \\
\hline
\end{tabular}

Fonte: CALASANS (1997); FILHO (1997) (grifos nossos).

No item 1, como se pode observar, Frias Filho ironiza o fato de que, embora o habitual da narrativa epopeica contemple a guerra contra um inimigo estrangeiro, o "inimigo estrangeiro" em Canudos fosse uma população cujo "estrangeirismo" não corresponderia à sua origem geográfica, mas à sua posição social. Tão apartada ela se encontrava socialmente que, na versão do EB, é referenciada como "população inculta". Frias Filho, no entanto, não manifesta juízo de valor contrário a essas pessoas: antes, ele as "defende", de modo que sua apreciação aí o aproxima de Calasans e o afasta do EB.

No item 2, outra "ironia" do diretor da Folha pode ser depreendida por meio da "estranheza" que ele registra, explicitamente: aqueles que segundo o EB "consideravam Canudos sua cidadela, independente do restante do País" e que praticavam "desmandos" pelas redondezas não eram "subversivos" no parecer de Frias Filho, pelo simples fato de que não pretendiam "subverter". Conforme assinalou Calasans, eles 
não objetivavam "restaurar a monarquia". Nas palavras de Frias Filho, no entanto, era essa a acusação insuflada desde o início pela imprensa "jacobina" da capital - adjetivo este que, de acordo com o Hoauiss, corresponde, num sentido pejorativo, ao que é avesso a estrangeiros ou ao que é estrangeiro ou incomum.

Haja vista que, inicialmente, o autor já se referira a um certo "estrangeirismo social" que marginalizava os canudenses, entende-se que, ao se manifestar contrário a essa "imprensa jacobina da capital" (e, aqui, talvez deixando entrever a linha geográfica que apartaria a perspectiva de quem está na capital da realidade daquele que está no sertão), Frias Filho se mostra favorável à outra parte, alinhado ao posicionamento de Calasans.

No item 3, finalmente, o diretor de redação da Folha se contrapõe ainda mais frontalmente ao posicionamento do EB, para o qual os seguidores de Conselheiros eram "incultos", "místicos", "fanáticos". Tratados como "retrógrados", eles são reivindicados no discurso de Frias Filho como "oprimidos", sendo que aos agressores - que se autorreferenciariam como "civilizados" - é que se destina essa crítica final, reiterando-se a ironia dos fatos: "a sociedade como um todo parece de cabeça para baixo ou deformada por efeito de alguma perversão interna". E foi essa "perversão interna" que se configurou no que Calasans chamou de "o maior equívoco da história nacional". Afinal, segundo o diretor de redação da Folha à época, "Canudos requeria ser integrada, não suprimida".

Diante do exposto, pode-se constatar que o posicionamento da Folha de S.Paulo acerca desse acontecimento histórico refuta a versão publicada pelo Exército, com a qual estabelece uma relação de antagonismo. Logo, compreende-se que, dado o espaço discursivo no qual os discursos se constituem, tanto a narrativa oficial dos militares quanto a própria narrativa euclidiana são (implícita e explicitamente) recuperadas visando-se à sua contestação, uma vez que o jornal faz circular uma imagem positiva da figura de Conselheiro e dos seus seguidores, condenando a supressão da população canudense - e, portanto, da intervenção militar tal como esta se deu.

\section{Considerações finais}

Conforme foi possível observar a partir dos próprios resultados apresentados por ocasião do levantamento realizado no site da Folha, a repercussão em torno do tema Guerra de Canudos é notável constatação da qual se pode inferir que, tão diversas quanto as publicações (dentro e fora da área acadêmica) acerca desse tema, também o são as perspectivas com que ele é tratado, configurando-se aí os diversos discursos postos em circulação a seu respeito. Esses discursos, no entanto, não se constituem individualmente, mas pela inter-relação que mantêm. No caso da Folha de S.Paulo, pôde-se analisar, por exemplo, como ela recupera - indiretamente - a versão oficial do Exército Brasileiro (o Outro na raiz do seu discurso) a fim de refutá-la não parcial, mas integralmente, manifestando, dessa forma, um posicionamento absolutamente contrário ao dessa instituição em relação aos mesmos tópicos abordados.

Partindo-se do pressuposto de que as práticas discursivas são também práticas sociais que, como tal, culminam com uma determinada leitura histórica do passado, pode-se ainda deduzir o modo pelo qual a prática discursiva desse veículo jornalístico influenciou/influencia direta e indiretamente na construção das memórias individual, coletiva e social por parte do seu leitor, construindo acerca da "epopeia" de Canudos uma imagem que se revela declaradamente distinta daquela produzida pelo Exército Brasileiro e, a propósito do que se registrou na Introdução deste trabalho, igualmente distinta daquela imagem construída pelo jornal que é considerado o seu principal concorrente, posto que, conforme as conclusões de Pinheiro (2015), o Estadão inicialmente associou Canudos à República ameaçada, visando a justificar a necessidade de uma ação bélica contra os sertanejos, retratando estes últimos como "fanáticos", "bandidos" e "inimigos".

Não obstante a mudança de posicionamento identificada por Pinheiro (2015) no discurso do Estadão, é possível vislumbrar ainda que ele, a exemplo do próprio Exército Brasileiro, constitui-se, discursivamente, como aquela parte de sentido que foi necessário o discurso da Folha sacrificar para 
constituir a sua própria identidade. Assim, ao se apresentar como "plural", "apartidária", "crítica" e "independente", a Folha visaria a antecipar quais os princípios que perpassam e/ou fundamentam o seu próprio posicionamento como jornal, sendo este um posicionamento que se forma no interior de um espaço no qual existem inúmeras outras instituições de cujos posicionamentos esse veículo de comunicação deseja se afastar - inclusive o do próprio Exército Brasileiro, que é uma instituição nacional, subordinada ao Ministério da Defesa do Governo Federal, ao passo que a Folha é "independente".

Mais objetivamente, ao reivindicar os princípios de "pluralismo", "apartidarismo", "jornalismo crítico" e "independência", a Folha já estaria manifestando, naturalmente, uma oposição àquelas instituições jornalísticas cuja análise quanto ao seu posicionamento poderia sugerir, sob o seu entendimento, uma "perspectiva estreita", um "partidarismo", um "jornalismo acrítico" e "dependente". Quando, por exemplo, Otávio Frias Filho se refere explicitamente a Euclides da Cunha - correspondente de guerra do Estadão durante a Guerra de Canudos e figura da qual o jornal muito se orgulha -, o então diretor de Redação da Folha estaria se apropriando da narrativa euclidiana para dela se distanciar discursivamente, criticando o posicionamento do autor de "Os Sertões" e, por extensão, o posicionamento daqueles que comungavam (e/ou que ainda comungam) do seu ponto de vista - logo, também o Estadão. Mais do que simplesmente "dados" e "acabados", portanto, os valores manifestados pela Folha de S.Paulo acerca da Guerra de Canudos foram e seguem sendo produzidos a partir da estreita relação que ela manteve e mantém com um Outro cuja existência não a interpela diretamente, mas a perpassa por si só. Um, na verdade, não dá "origem" ao Outro: todos os discursos vão sendo forjados simultaneamente no interior do espaço no qual despontam.

Além disso, dadas as diferentes apreciações acerca do mesmo evento, corrobora-se, ainda, o postulado por Jenkins (2001), quanto ao passado e a história não estarem unidos um ao outro de tal maneira que se possa ter uma, e apenas uma única leitura histórica do passado, bem como corrobora o que diz respeito às diferentes possibilidades de interpretação sobre um mesmo objeto de investigação analisado sob diferentes práticas discursivas. Nesse sentido, cumpre retomar, oportunamente, a distinção explicitada entre história e memória, acrescentando-se aqui que, ao convidar um especialista como José Calasans para escrever em caráter especial ao jornal por ocasião do centenário da morte de Conselheiro, a Folha não estaria tão somente veiculando "memória", mas fazendo circular um conhecimento histórico, dado se tratar da publicação de um historiador cujos estudos foram realizados seguindo-se uma metodologia científica. Já a "história" compartilhada pelo Exército Brasileiro (tanto quanto aquela veiculada pelo Estadão e, por que não dizer, pelo próprio Euclides da Cunha), corresponderia, na verdade, a uma "memória". Num intervalo de cem anos, é a memória que explica, por exemplo, o porquê de Conselheiro ter passado de "charlatão e louco", como era chamado pelos padres e pela polícia da Bahia, e de "fanático", como permanece sendo referenciado pelo EB, a líder popular e "herói da pátria", tal como o projeto de lei no 6753/16, de autoria da deputada federal Luizianne Lins (PT/CE) (GAMA, 2017), e a "Santo Conselheiro", tal como Calasans (1997) a ele se refere.

Finalmente, tendo-se em vista que, em razão das motivações ideológicas, religiosas, políticas, doutrinárias, coletivas, etc. que se sucedem, a construção da memória pode sofrer variações a cada período, é de se questionar se haverá ainda, daqui a algum tempo, uma mudança na versão oficial dos acontecimentos em Canudos divulgada pelo Exército Brasileiro. Isto, porém, somente a própria História dirá.

\section{Notas}

[1] O corpus de Pinheiro (2015) foi constituído por textos do Estadão publicados durante a guerra (de 1896 a 1897), no período do lançamento de "Os Sertões" (1902), no mês da morte de Euclides da Cunha (1909) e de datas supostamente comemorativas dos séculos XX e XXI (os centenários).

[2] De acordo com o Houaiss (2018, grifos nossos), os sentidos do termo "oficial" podem ser, entre outros, "1 emanado do governo ou de uma autoridade administrativa reconhecida «ato o.> 2 certificado 
pela autoridade pública ou por uma autoridade competente «nota o.» 3 pej. apresentado como verdade pela autoridade pública ou por uma autoridade reconhecida 〈a versão o. dos fatos〉”.

[3] Disponível em: <https://www1.folha.uol.com.br/institucional/circulacao.shtml>. Acesso em: 3 jun. 2018.

[4] Em "Gênese dos Discursos", Maingueneau (2008, p. 33) propõe "tornar menos grosseiro este termo muito vago e substitui-lo por uma tríade: universo discursivo, campo discursivo, espaço discursivo". Não obstante a importância da referida tríade, para esta pesquisa optou-se por não se discorrer a respeito do que configuraria cada um desses conjuntos, uma vez que o estudo se situa no campo da História Militar e que o aprofundamento da teoria possivelmente demandasse a mobilização de conhecimentos mais peculiares ao campo da própria Linguística.

[5] "O livro transcreve manuscritos de Antônio Conselheiro, líder da Revolta de Canudo (1896-1897), intitulados 'Prédicas aos canudenses e um discurso sobre a república', datados do local dos acontecimentos: Belo Monte, Bahia, 1897. Tais manuscritos foram encontrados no arraial rebelde dizimado e presenteados a Euclides da Cunha, que não chegou a utilizá-los em sua obra Os sertões. Descobertos muitos anos depois num sebo carioca, constam de anotações para as prédicas do Conselheiro sobre temas religiosos e políticos, com destaque para a república. Antecede a transcrição do documento histórico um estudo do autor reavaliando a atuação e o pensamento do líder popular." Disponível em: <http://www.brasiliana.com.br/brasiliana/colecao/obras/465/antonio-conselheiro-ecanudos>. Acesso em: 18 ago. 2018.

[6] Consoante Macedo e Maestri (2004), em 1830.

[7] Conforme Motta (2017, n.p.), "Sem ter nenhum vínculo mais estabelecido com a monarquia e com monarquistas de outras regiões (apesar de que isso foi extensamente propagado pela imprensa da época), Antônio via a forma ideal da monarquia sendo expulsa da vida brasileira e substituída pela forma degradada em sua visão da república".

[8] Ao que se pode considerar, tal como exposto na Introdução desta pesquisa, que o Estadão estava entre esses jornais.

\section{Referências}

ARARIPE, T. A. Expedições militares contra Canudos: seu aspecto marcial. 2. ed. Rio de Janeiro: Biblioteca do Exército, 1985.

CALASANS, J. Belmonte resiste. Revista da Bahia: Guerra de Canudos 100 anos de penitência, Salvador, v. 32, n. 22, nov. 1996.

. O Bom Jesus do sertão. Folha de S.Paulo, [S.1.], 21 set. 1997. + mais! Disponível em:

<https://www1.folha.uol.com.br/fsp/mais/fs210907.htm>. Acesso em: 9 jul. 2018.

CHARADEAU, P.; MAINGUENEAU, D. Dicionário de análise do discurso. 2. ed. Tradução Fabiana Komesu. São Paulo, Contexto, 2008.

CUNHA, E. Os sertões. São Paulo: Ubu Editora, 2016.

EXÉRCITO BRASILEIRO. Campanha de Canudos. Disponível em:

$<$ http://www.eb.mil.br/exercito-

brasileiro?p_p_id=101\&p_p_lifecycle=0\&p_p_state $=$ maximized\&p_p_mode $=$ view\&_101_struts_acti on $=\% 2$ Fasset_publisher $\% 2$ Fview_content $\& \_101 \_r e t u r n T o F u l l P a g e U R L=\% 2 F \& \_101 \_a s s e t E n t r y I d=$ 1542044\&_101_type $=$ content\&_101_urlTitle=campanha-de- 
canudos\&_101_redirect $=$ http $\% 3 \mathrm{~A} \% 2 \mathrm{~F} \% 2 \mathrm{Fwww}$. eb.mil.br $\% 2$ Fexercito-

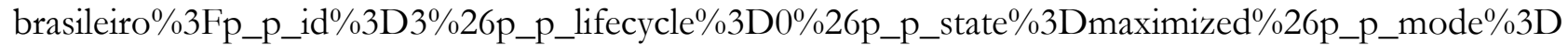
view $\% 26$ 3_redirect $\% 3 \mathrm{D} \% 252 \mathrm{~F} \% 26$ 3_keywords $\% 3 \mathrm{DCANUDOS} \% 26$ 3_groupId $\% 3 \mathrm{D} 0 \% 26$ _3_str uts_action $\% 3 \mathrm{D} \% 252 \mathrm{Fsearch} \% 252 \mathrm{Fsearch} \&$ inheritRedirect=true $>$. Acesso em: 11 jun. 2018.

FOLHA DE S.PAULO. Conheça o Grupo Folha. Disponível em:

$<$ https://www1.folha.uol.com.br/institucional/>. Acesso em: 11 jun. 2018.

FRIAS FILHO, O. Canudos sobrevive. Folha de S.Paulo, [S.l.], 2 out. 1997. Opinião. Disponível em: <https://www1.folha.uol.com.br/fsp/1997/10/02/opiniao/7.html>. Acesso em: 9 jul. 2018.

GAMA, L. Antônio Conselheiro poderá ser reconhecido oficialmente como Herói da Pátria. Rádio Câmara, Câmara dos Deputados, 28 nov. 2017. Disponível em:

<http://www2.camara.leg.br/camaranoticias/radio/materias/RADIOAGENCIA/549878-

ANTONIO-CONSELHEIRO-PODERA-SER-RECONHECIDO-OFICIALMENTE-COMO-

HEROI-DA-PATRIA.html>. Acesso em: 7 jun. 2018.

HOUAISS, Antônio. Dicionário Houaiss da Língua Portuguesa. Disponível em:

<https://houaiss.uol.com.br/pub/apps/www/v3-3/html/index.php\#0>. Acesso em: 20 jul. 2018.

JENKINS, K. A história repensada. São Paulo: Contexto, 2001.

MACEDO, J. R.; MAESTRI, M. Belo Monte: uma história da Guerra de Canudos. São Paulo: Expressão Popular, 2004.

MAINGUENAU, D. Gênese dos discursos. Tradução Sírio Possenti. São Paulo: Parábola Editorial, 2008.

Discurso e análise do discurso. Tradução Sírio Possenti. São Paulo: Parábola Editorial, 2015.

MARTINS, P. E. M. A reinvenção do sertão: a estratégia organizacional de Canudos. São Paulo: FGV, 2001.

MILTON, A. A campanha de Canudos. Rio de Janeiro: Imprensa Nacional, 1902.

MOTTA, R. G. Antônio Conselheiro e João Abade: a teoria do estado e Canudos. Guaratinguetá: Sodebrás, 133, v. 12, p. 18-23, 2017.

NOGUEIRA, J. C. A. Antônio Conselheiro e Canudos: revisão histórica. A obra manuscrita de Antônio Conselheiro e que pertenceu a Euclides da Cunha. E. ed. São Paulo: Editora Nacional, 1978.

O JORNAL mais influente do País. Folha de S.Paulo. Disponível em:

<https://www1.folha.uol.com.br/institucional/o_grupo.shtml?fill=1>. Acesso em: 9 jul. 2018.

PARENTE, P. A. L.; SANCHES, M. G. Teoria e metodologia da história: livro didático. Palhoça: UnisulVirtual, 2009.

PINHEIRO, L. S. L. A Comemoração do Fato Histórico no Jornal. Intercom - Sociedade Brasileira de Estudos Interdisciplinares da Comunicação XXXIV. Congresso Brasileiro de Ciências da Comunicação - Recife, PE - 2 a 6 de setembro de 2011. Disponível em:

<http://www.intercom.org.br/papers/nacionais/2011/resumos/R6-1732-1.pdf>. Acesso em: 31 mai. 2018.

A construção do acontecimento histórico: o discurso do jornal O Estado de São Paulo sobre a Guerra de Canudos e sobre as comemorações do seu centenário. Salvador: EDUFBA, 2015. 